\title{
HOME VERSUS SCHOOL LEARNING: A NEW APPROACH TO ESTIMATING THE EFFECT OF CLASS SIZE ON ACHIEVEMENT**
}

\author{
Mikael Lindahl** \\ University of Amsterdam
}

This draft: 4 March 2001

(First draft: 18 September 1999)

\begin{abstract}
I estimate the effect of class size on scholastic achievement using that schools are only in session during the school year and out of session during the summer. This seasonal feature of the schooling system makes it possible to control for unobservable pupil characteristics affecting both the level and change in achievement. Using Swedish data, I find that smaller classes generate higher achievement and that this effect is larger for some disadvantaged groups. A comparison with the results from applying the same data to the widely used value-added model is also made.
\end{abstract}

* This study was conducted when I was affiliated with the Swedish Institute for Social Research, Stockholm University. I have benefited from many valuable comments from Anders Björklund, Per-Anders Edin, Daniel Hallberg, Martin Hörnqvist, Alan Krueger, Maria Melkersson, Lena Nekby-Conde, Roope Uusitalo, Diane Whitmore, Olof Åslund and from seminar participants at SOFI, IUI, Uppsala University, EALE/SOLE 2000, EEA 2000, IZA and Tinbergen Institute. I also thank Ossian Wennström and Peter Björklund for excellent help with the data collection, and Judy Petersen for improving the language. Financial support from HSFR and Handelsbanken is gratefully acknowledged. I also thank the pupils and teachers that participated in this study.

** Department of General Economics/NWO 'Scholar', Faculty of Economics and Econometrics, University of Amsterdam, NL-1018 WB, Amsterdam, The Netherlands. Email: mlindahl@fee.uva.nl. The author is also affiliated with IZA, Bonn. 


\section{Introduction}

Recent economic research has given much attention to the effect of school quality on pupils' achievement and their subsequent socioeconomic success as adults. ${ }^{1}$ One issue that has been particularly highlighted is the effect of class size on these outcome variables. The reason for the interest in this particular issue might stem in part from conflicting results in the literature, and because this is a school policy instrument that is easy to understand and to implement.

Ideally, for estimating purposes, pupils and teachers should be randomly assigned to classes of different sizes. The only randomized experiment ever conducted started in Tennessee in $1985 .{ }^{2}$ Pupils and teachers were randomly assigned to regular-sized and smaller classes. Krueger [1999], re-examining the data, finds significant, positive effects from smaller classes on achievement, and that this effect is larger for black, economically disadvantaged and inner-city children. Even though the experiment ended after third grade, Krueger and Whitmore [2000], find that those pupils assigned to small classes still has somewhat higher test scores in eight grade and have a higher probability of taking the college-entrance exams. This last effect was especially prevalent for black pupils, making the black-white gap in college-entrance exam takings to decrease by 54 percent.

But most often, researchers must rely on identification strategies other than randomized experiments. This is probably why the question of whether smaller school classes generate a higher achievement level is still debated in the academic literature. This might be especially true, since school resources, and thereby smaller classes, often are directed toward low-achieving pupils. This creates class size estimates in observational studies that are biased away from finding positive achievement effects of smaller classes. ${ }^{3}$ 
Angrist and Lavy [1999] uses a regression-discontinuity design to identify class size effects. More specifically, they employ an exogenous variation in class size due to a rule that determines the maximum number of pupils in classes in Israel. They found significant, positive effects from smaller classes on achievement, which were at the lower end of the estimates from Krueger [1999]. Hoxby [2000] use discontinues jumps in class sizes between US school districts to identify the effect of class size on achievement, finding small and non-significant effects from smaller classes. Hoxby also get similar results from using another identification strategy that exploits natural variation in pupil cohorts between U.S. school districts. Dobbelsteen, Levin and Oosterbeek [1999] estimate class size effects by modeling the distribution of school resources among Dutch schools. In general, their class-size estimates were not statistically significant different from zero. Case and Deaton [1999] use the fact that in South Africa, during the apartheid regime, black people were neither able to choose location nor to influence school expenditures in the districts in which they lived. The variation in class size among black pupils was also extraordinarily large during this period. They find that for black pupils, smaller pupil-teacher ratios increase test scores, educational attainment, and the probability of still being enrolled in school.

The most common way to estimate the effect of class size on achievement has been to estimate a value-added model. This specification estimate changes in achievement, usually measured at the end of two subsequent grades, against variables such as class size and teacher characteristics. Under certain assumptions, the class-size estimate can be interpreted as the effect of class size on achievement. In Hanushek [1992], who estimate value-added specifications, no significant effect from smaller classes was found. In 
Hanushek [1998], updating Hanushek [1986], 78 estimates taken from many different studies using the value-added model are listed. Only 12 percent of these estimates were statistically significant positive estimates of teacher-pupil ratios on student performance. Hanushek, Kain and Rivkin [2000] also estimate value-added models. They use a sample of more than 200,000 pupils in Texas and found significant but small effects from smaller classes for pupils in fourth and fifth grades, and insignificant effects for pupils in sixth grade.

The purpose of this paper is to estimate the causal effect of class size on achievement, using new Swedish data. To do this, I present a new way to estimate the effect of class size on achievement. This method is built around the fact that schools are closed during the summer but open during the school year. This seasonal feature of schooling in Sweden (and in most other countries) makes it possible to separate the effect of family background and schooling on learning. ${ }^{4}$ During the school year, characteristics in the school as well as family background characteristics probably all affect learning (i.e. achievement change), whereas during the summer, only family background characteristics will affect learning. By examining the difference between school year and summer learning, it is possible to isolate the effect of school characteristics, such as class size, on achievement. Since the value-added specification is a special case of this difference-indifferences specification, a comparison of these two models is possible and will be made.

I apply these models to a new sample of 556 Swedish fifth and sixth grade pupils. ${ }^{5}$ The sample contains scores on identical mathematics tests for the same pupils at the end of the fifth grade and at the beginning and end of sixth grade. ${ }^{6}$ It also contains measures of class size for each grade, teacher variables and information on pupils' social backgrounds. 
The pupils are from 16 schools within the Stockholm municipality area in Sweden. The sample is a stratified random sample of all schools in the Stockholm municipality. A total of 38 school classes participated.

The results from the analysis in this paper are that estimations using the valueadded specification yield class-size estimates that are insignificantly different from zero. But applying the same data to a difference-in-differences specification that eliminates unobservable pupil learning fixed effects, on the contrary, yields significant positive achievement effects of smaller classes, and these estimates are not far away from those in the Tennessee experiment.

In the next section, I present the estimation strategy and compare the value-added specification to the difference-in-differences specification. Section III presents the data set and some descriptive statistics. In section IV, I relate achievement to class size using new Swedish data. Whether the effect of smaller classes on achievement differs among pupils with different social backgrounds is also investigated. I also discuss and test how sensitive the results are to relaxation of some important assumptions underlying the estimations. Section V contains a discussion.

\section{Model and Estimation Techniques}

In this section, I first discuss a common way of estimating parameters in educational production functions, which is the value-added estimation technique. I then show an alternative way to estimate educational production functions, which requires different data than is usually available but has the advantage of enabling relaxation of a strong assumption, which is necessary to make in the traditional value-added approach. 


\section{A. Educational Production Functions and the Value-added Model}

A value-added model can be expressed as:

$$
A_{i t}-A_{i t-1}=\theta+\phi F_{i t}+\beta S_{i t}+v_{i}+u_{i t},
$$

where $A_{i t}-A_{i t-1}$ is the change in achievement level for pupil $i$ that has occurred between the end of grade $t-1$ and the end of grade $t ; F_{i t}$ denotes a vector of demographic, family background, and neighborhood characteristics in grade $t ; S_{i t}$ denotes a vector of schooling variables such as class size and teacher quality in grade $t$ and $\theta$ is an intercept. The error term in (1) is assumed to consist of two parts, $v_{i}$ which is a (time) fixed learning effect that captures family background, innate ability, and everything else that has constant influences on achievement change for pupil $i$ during period $t$ and $u_{i t}$, which is a random error term that is assumed to be orthogonal to $F_{i t}, S_{i t}$ and $v_{i}{ }^{7}$

If lagged achievement level is allowed to affect the change in achievement between grades we can instead write (1) as:

$$
A_{i t}=\theta+\phi F_{i t}+\beta S_{i t}+\lambda A_{i t-1}+v_{i}+u_{i t} .
$$

In both equations (1) and (2), the lagged achievement level, $A_{i t-1}$, captures all the previous observed and unobserved pupil, family, neighborhood, and school characteristics, as long as these characteristics affects the level of achievement and not the change in achievement. $^{8}$ These characteristics, including any unobserved fixed achievement level effect before school starts, do hence not biasing parameter estimates of equation (1). Equations (1) and (2) are in the following referred to as the value-added specifications. ${ }^{9}$

A puzzle in the class-size literature is that the popular value-added specification generally has generated small and insignificant class-size estimates. Krueger [1999] 
points out that if the effect of class size is largest the first year a small class is attended (which is the case in the Tennessee data), this specification underestimates the class-size effect on achievement if estimations are done on data for later grades. Because the effect of previous class sizes on achievement level is eliminated, by controlling for lagged achievement level, interpreting $\beta$ as the average effect requires an assumption that this effect is a good approximation of class-size effects also in previous grades.

Another potential drawback with the value-added model is that it fails to eliminate the fixed learning effect, $v_{i}$. The reason for this is that in (1) and (2), we have allowed unobservable time-constant factors to have an effect on achievement growth through the fixed learning effect, besides a one-time effect on achievement level. If the fixed learning effect is correlated with $F_{i t}$ or $S_{i t}$, all parameter estimates will be biased. The approach outlined in the next section attempts to eliminate biases due to both fixed learning effects, as well as fixed achievement level effects.

\section{B. An Alternative Way to Estimate Educational Production Functions}

In the previous section, we assumed that achievement level could only be measured at the end of each grade level, $t$ and $t-1$. Suppose achievement level could also be observed at the start of each school year. For expository purposes, assume that each grade level consists of two parts of equal length, the summer vacation and the school period. In reality the summer period is much shorter then the school period but the sensitivity to this assumption will be dealt with in the empirical section. The part of grade $t$, when school is in session, is denoted $j=2$, and the part of the grade, where school is out of session, i.e. the summer vacation, is denoted $\mathrm{j}=1$. 
Assuming that previous achievement level do not affect the change achievement during the summer and during the school year, equation (1), at grade $\mathrm{t}$ (for $\mathrm{j}=1,2$ ) can then be expressed as:

$$
\begin{aligned}
& \Delta A_{i t, 1}=\kappa_{1}+\alpha_{1} F_{i t}+\delta_{i}+\varepsilon_{i t, 1} \\
& \Delta A_{i t, 2}=\kappa_{2}+\alpha_{2} F_{i t}+\beta S_{i t}+\delta_{i}+\varepsilon_{i t, 2},
\end{aligned}
$$

where $\Delta A_{i t, 1}=A_{i t, 1}-A_{i t-1,2}$ is the achievement change during the summer period; $\Delta A_{i t, 2}=A_{i t, 2}-A_{i t, 1}$ is the achievement change during the school period; $A_{i t, 1}$ is achievement level at the start of the school year in grade $t ; A_{i t-1,2}$ is achievement level at the end of the school year in grade $t-1 ; A_{i t, 2}$ is achievement level at end of school period in grade $t ; F_{i t}$ denotes a vector of demographic, family background, and neighborhood characteristics in grade $t ; S_{i t}$ denotes a vector of schooling variables such as class size and teacher quality in grade $t$; and $\kappa_{1}$ and $\kappa_{2}$ is intercepts allowing the average achievement change to be different during the school and summer periods. The error terms are assumed to consist of two parts; $\delta_{i}$ which is the fixed learning effect and $\varepsilon_{i t j}$ which are random error terms. The latter terms are assumed not to be correlated with $F_{i t}, S_{i t}$ and $\delta_{i \cdot}{ }^{10}$

Equation (3) expresses summer learning as a function of family background, previous achievement level, and the fixed learning effect. Equation (4) expresses learning over the school period as a function of family background, school characteristics, previous achievement level and the fixed learning effect. The important difference between equation (3) and equation (4) is that schooling characteristics affect achievement only when schools are in session, whereas family background characteristics influence 
achievement when schools are in session and when they are not. Note that equation (1) is a special case of equations (3) and (4), since the difference is that in equation (3) and (4), grade level $t$ is divided into a summer, when $\mathrm{j}=1$, and a school period, when $\mathrm{j}=2 .{ }^{11}$

Note that since schools are out of session during the summer, they cannot influence learning in grade $t$, when $\mathrm{j}=1$. This makes the achievement level in grade $t$, when $\mathrm{j}=1$, depend on cumulative schooling factors only until time period $t-1 . A_{i t, 1}$ and $A_{i t-1,2}$ are both functions of all previous pupil, family, neighborhood and school characteristics, including an individual-specific achievement effect that captures the unobserved achievement level before the school starts.

In the following, we will assume that in equations (3) and (4), the parameters linking family background to achievement, are the same at the end of the summer and at the end of the school period, i.e. $\alpha_{1}=\alpha_{2} \cdot{ }^{12}$

We can eliminate the fixed learning effect by taking the difference between (4) and (3) to get:

$$
\Delta A_{i t, 2}-\Delta A_{i t, 1}=\kappa^{\prime}+\beta S_{i t}+\Delta \varepsilon_{i t, 2}
$$

where the dependent variable is the difference between learning during the school and summer periods; $\Delta \varepsilon_{i t, 2}=\varepsilon_{i t, 2}-\varepsilon_{i t, 1}$; and $\kappa^{\prime}=\kappa_{2}-\kappa_{1}$. Estimation of equation (5) will produce consistent estimates of the effect of class size on pupils' achievement levels, i.e of $\beta$, if the assumption that lagged test scores do not affect changes in test scores, conditional on family and schooling characteristics, is correct.

The identification strategy becomes more complicated if lagged achievement level is allowed to have an effect on the achievement change. Equations (3) and (4) are then expressed as: 


$$
A_{i t, 1}=\kappa_{1}+\alpha_{1} F_{i t}+\gamma_{1} A_{i t-1,2}+\delta_{i}+\varepsilon_{i t, 1}
$$

$$
A_{i t, 2}=\kappa_{2}+\alpha_{2} F_{i t}+\beta S_{i t}+\gamma_{2} A_{i t, 1}+\delta_{i}+\varepsilon_{i t, 2}
$$

where equations (6) and (7) are generalizations of equation (2). Taking the difference between (7) and (6), assuming $\alpha_{1}=\alpha_{2}$, we get:

$$
\Delta A_{i t, 2}=\kappa^{\prime}+\beta S_{i t}+\gamma_{2} \Delta A_{i t, 1}+\Delta \gamma A_{i t-1,2}+\Delta \varepsilon_{i t, 2}
$$

where $\Delta \gamma=\gamma_{2}-\gamma_{1}$. It is not possible to estimate the class size parameter in equation (8) consistent unless some restriction is imposed.

If we assume that $\gamma_{1}=\gamma_{2}=\gamma$, that is, previous test score level has the same effect on the change in test scores during the summer and during the school year, we can rewrite (8) to get:

$$
\Delta A_{i t, 2}=c^{\prime}+\beta S_{i t}+\gamma \Delta A_{i t, 1}+\Delta \varepsilon_{i t, 2} .
$$

Due to the correlation between $\Delta A_{i t, 1}$ and $\Delta \varepsilon_{i t, 2}\left(\right.$ since $\left.\operatorname{cov}\left(A_{i t, 1}, \varepsilon_{i t, 1}\right) \neq 0\right)$, the parameter estimates will be biased if equation (9) is estimated by OLS. So we instead estimate this equation by using $A_{i t-1,2}$ as an instrument for $\Delta A_{i t, 1} \cdot{ }^{13}$ Estimates of the parameters in (9), could be inconsistent for at least four reasons. First, a failure of the necessary assumption of no serial correlation in the error terms, i.e. $\operatorname{cov}\left(\varepsilon_{i t 2}, \varepsilon_{i t 1}\right)=0$. Second, a failure of the necessary assumption that $\gamma_{1}=\gamma_{2}$. By comparing equations (9) and (8) it is clear that if lagged test score levels have different effects over the summer and over the school year, then $\gamma$ in equation (9) is not identified since we are not able to use $A_{i t-1,2}$ as instrument for $\Delta A_{i t, 1}$ (see discussion in section IV.B). Third, that $A_{i t-1,2}$ has no statistically significant effect on $\Delta A_{i t, 1}$, conditional on the other variables. Fourth, if test scores are measured with 
errors, all parameters in (9) will be inconsistently estimated. I therefore correct the estimates in (9), by using an estimate of the reliability ratio for the test scores. ${ }^{14}$ Note that measurement error in the test scores or serial correlation in the error terms does not bias estimates of $\beta$ in (5).

The main difference between equations (1) and (2) and equations (5) and (9), is that the last two specifications eliminates the unobservable fixed learning effect, whereas the first two specifications do not. In the following, equations (5) and (9) are referred to as the difference-in-differences approach to estimate educational production functions. ${ }^{15}$

So far I have emphasized the advantage of my proposed difference-in-differences approach compared to the value-added model. However, both models share a crucial assumption, namely that unobserved current school characteristics do not bias the classsize estimate. If class size is correlated with other class or school characteristics that also have an effect on the achievement level and that we cannot adequately control for, biased estimates of class-size effects will occur. In the estimations in the next section, we therefore control for teacher experience overall and in the present class. We should not need to control for teacher education because all teachers but one were certified and had a bachelor's degree as their highest scholastic credentials. ${ }^{16}$ Estimations with controls for school effects, by including school dummies, are also done. Another problem with the difference-in-differences model could be that the fixed learning effect is of different magnitude in the summer and school period regressions. This issue is discussed further in section VI.D.

Both the value-added and the difference-in-differences specifications cancel out previous school characteristics. So we can use previous class sizes as instruments for 
present class size. The purpose of this is twofold. First, the elimination of measurement error bias (if errors of measurement for observational class sizes in different grades are not correlated), and second, the elimination of endogeniety bias, due to unobservable schooland class characteristics (if previous class size is not correlated with these unobservable variables), in the class-size estimates.

\section{Data}

Pupils in most schools in Sweden take a mathematics test that is distributed by the Swedish National Agency for Education and given early in the spring semester of the fifth

grade. I contacted schools at the start of the fall 1998 semester. I selected four parts of this test, which I then distributed to the pupils at the start and end of the sixth grade. The spring of the fifth grade test were given during the February-June period, with the four test parts conducted at separate occasions. The fall of the sixth grade test were given from the last week in September to the first week in November, and the spring of the sixth grade test were given during the last four weeks of the term (in May-June). The summer vacation in Sweden lasts 10 weeks, from early June to late August. I, with some assistance, graded the tests were on all three occasions. In total, 556 pupils did at least one part of the test on all three occasions, and took the test under similar conditions regarding time allowed and teacher help. ${ }^{17}$ The same test was used on all three occasions. A consequence of this might be that observed test score changes only partly reflect true achievement changes, due to so-called re-test bias. This issue is investigated further in section VI.D. The test parts included in each test were of different kinds, with questions ranging from simple counting exercises too more advanced problems. The average 
percentile rank over the four test parts (on each test occasion) was then used as the measure of each pupil's achievement in mathematics for the time periods in question. ${ }^{18}$

Table I present summary statistics for test scores in spring of the fifth grade, fall of the sixth grade and spring of the sixth grade. ${ }^{19}$ In the value-added regressions, the change in test score between spring of the fifth grade and spring of the sixth grade is used as dependent variable. In the difference-in-differences regressions, the difference between test score changes over the school period (fall of the sixth grade and spring of the sixth grade) and test score changes over the summer (spring of the fifth grade and fall of the sixth grade) are used as dependent variable. In practice, the length between the conducted test dates, for the summer test period and the school test period, were very close. ${ }^{20}$ If the school does not contribute to learning in the beginning and end of the school year, it can be assumed that the summer test score changes are well captured by our observed test score changes over the summer.

More likely however, this is not the case. I therefore check the sensitivity to this, by predicting test scores at the last week of school in spring of the fifth grade and spring of the sixth grade, and at the first week of school in the fall of the sixth grade. This is done by assuming that learning is linear during the school year. ${ }^{21}$ If this is true, and since I know when the tests were done, predicting test scores at the first and last week of sixth grade is straightforward. Since these tests were not administrated at the beginning of the fifth grade, predicting test scores at the end of fifth grade is more complicated. I attempt to do this by assuming that the individual learning rate in fifth grade, is reasonably well approximated by the estimated individual learning rate in sixth grade, net of class size effects. $^{22}$ It is important to point out, however, that if pupils' school period learning 
decreases with weeks spent in school, using the observed test score changes might give a more accurate estimate of the class size effect. ${ }^{23}$ The tests took place at different times in different schools during the semesters. Since we know when the test took place in each school, this is taken into account in the predicted scores.

Data on school, class, and teacher characteristics were gathered with a questionnaire distributed to the teachers at the time of the fall sixth grade test. Teachers were asked to answer questions about themselves (their teaching experience and education) and their students (pupils' genders and nationality of pupils' parents) and to provide information about their class size. ${ }^{24}$ To get information on pupils' social background, the addresses of the pupils (from the class lists) were matched with block data on education and family income. ${ }^{25}$ These data are taken from Statistics Sweden databases and were partly calculated by them for the purpose of this project. ${ }^{26}$

A class is counted as the group of pupils to whom mathematics is taught. Many previous analyses of class-size effects have used aggregated data on class size (or pupilteacher ratios) at the district or school level. Hanushek [1998] provides a tabulation of more than 277 available estimates from the literature on the effect of teacher-pupil ratios on achievement. Only 28 percent of the estimates are from estimations using classroom data. It seems that the likelihood of getting positive teacher-pupil ratio effects on achievement increases in the level of aggregation levels. A reason for this could be that, if weak pupils are put in smaller classes, this re-distribution of school resources is mainly done within schools. Hence, aggregated data can give a more accurate estimate of the true class size effect. However, fixed achievement or learning effects is likely to be present also in aggregated data. Also, if distribution of school resources is done mainly between 
areas, class size estimates that uses aggregated data will be more biased compared to estimates using pupil data. ${ }^{27}$

In this paper, I have the possibility of using two measures of class size. The first is the class size that is present during mathematics instruction, which is labeled math classes. The second is the class size that is present during teaching in the typical subject, which are labeled regular classes. I focus primarily on the math classes, since the tests used in this study is designed to capture math skill. Figure 1 shows the distribution of math class size.

In Table II, class sizes in grade five and six are correlated with demographic and family-background variables. Pupils with parents, who are less educated, have lower family incomes, and have ethnic backgrounds other than Swedish are found in smaller classes. This is expected, since in Sweden educational resources are redistributed towards schools with pupils from socially disadvantaged backgrounds. ${ }^{28}$ If the variation in class size is broken down by family background, it shows that it decreases with parents' socioeconomic status and is higher for pupils with non-Swedish parents. There is however still large variation in class sizes within all these groups. ${ }^{29}$ In some of the estimations later on we control for school fixed effects. Note however that three schools have no variation in class size. This means that in the regressions including school fixed effects, only 445 pupils contribute to the estimated class size effect. Note also that almost two-thirds of the variance in actual class size is due to between-schools variation. The estimations using school fixed effects should therefore be interpreted with some care.

Table II also shows that the correlation between math and regular class sizes is only 0.42 in sixth grade. Note however, that the math and regular class size measure is identical for 295 pupils. The variance for the regular class size measure is only somewhat 
higher then the actual class size measure (19.39 vs. 17.29). Both these variances are high compared to many other data sets. One reason for this is probably that both these class size measures are relatively more disaggregated. Since the class size information were carefully collected, based on personal interviews with the teacher in the class, for some classes it was the case that even though the official class lists contains some number of pupils, it was made clear to me that in reality the teaching were done in smaller groups. It is probably the case that in many other data sets the variation in class size within schools are smaller then in this data set. Since the main source of variance in math class sizes stem from between school variation, one needs also note the redistributive policy in Sweden regarding school resources, mentioned above. Since the math class size measure most correctly will represent the actual number of pupils taught in math for pupils, I focus in this measure throughout the paper.

\section{Results}

Table III shows the correlation between results from the three test periods. The correlations between test scores in the spring of the fifth grade, fall of the sixth grade, and spring of the sixth grade are between $0.72-0.77$. Table IV shows a correlation matrix among the four parts of the test, done in the spring of the fifth grade. The results on these test parts could, for some reasons, deviate from the true results. But because these test parts were all conducted on different occasions and were of different kinds, these deviations are likely to be independent from one another. ${ }^{30}$ If these deviations are also independent of the true test scores, we can get an estimate of the reliability of the average test score on each test occasion by calculating the alpha reliability. ${ }^{31}$ The alpha reliability 
is a measure of the ratio of the true variance to the observed variance, which is calculated from two or more independent measures. The alpha reliability is estimated to be 0.7878 . In later estimations, this reliability ratio is used to correct the estimates for measurement errors in the test scores. The reliability ratio for the change in test scores is 0.3461 .

Note that the estimates of the standard errors in this section relaxes the assumption of uncorrelated regression errors among pupils, since unobserved teacher, class and school characteristics might make this assumption unrealistic. Instead we allow for correlated regression errors among pupils within the same school.

\section{$\underline{\text { A. Level and Value-added Regressions }}$}

To illustrate what potential sources of biases that can occur in achievement level regressions on class size, I start by regressing the spring of the sixth grade test scores on class size the same year. Table V reports these level regressions. The estimate in column 1 indicates a positive association between math class size and test scores. ${ }^{32}$ Interpreting this estimate as a causal effect of class size, an increase in class size by one pupil would give, on average, 1.5 percentile ranks higher test score. Adding family background and demographic variables to the regression decreases the estimate to about half of the previous one. ${ }^{33}$ This points toward a compensatory distribution of school resources in this data. It also indicates that the class-size estimate in column 1 is biased. Adding teacher experience and school dummy variables does not change the estimate. The obvious drawback with the specifications underlying Table $\mathrm{V}$ is that is that class size is unlikely to be exogenous. Instead, observed class size is probably correlated with other school and class characteristics and with pupils' family background in the present and/or the previous 
time periods. Because it is impossible to completely account for these factors in estimations, these estimates are probably biased estimates of the causal effect.

In Table VI we turn to the value-added specifications, such as equations (1) and (2). Note that the estimate on lagged achievement from equation (2), is presented in Table VI as $\lambda-1$, to facilitate comparison with equation (1). Also note that the estimates of equation (2) are adjusted for classical measurement error in test scores, by assuming the reliability ratio to equal 0.7878 . Whether or not test score at the start of the period is controlled for, the class-size estimates are insignificantly different from zero or positive and significant. This result is consistent with the pattern in the literature that uses variations of the value-added specification. Additional estimates reveal a quadratic pattern for teacher experience, that is, more teacher experience adds to pupils' achievement but at a decreasing rate. The number of years the teacher has taught this math class, has a negative significant or insignificant effect on the test scores. The observable demographic and family-background variables are not jointly significant in any of the specifications. If the fixed learning effect, $v_{i}$, is poorly proxied for by these family background and demographic variables, unobservable variables could still bias the estimates of the effects of class size and teacher variables in Table VI.

\section{$\underline{\text { B. Difference-in-differences Regressions }}$}

Table VII shows the estimates from the difference-in-differences specification, namely equations (5) and (9), where the estimates of equation (9) are adjusted for classical measurement error in test scores (assuming the reliability ratio to equal 0.7878 ). Strikingly, in all estimations, the class-size effect becomes significantly negative. This 
result is robust, whether or not lagged test scores are controlled for, teacher variables are added, or fixed school effects are included. Most specifications in Table VII reveal a quadratic pattern for teacher experience. These estimates are only sometimes significantly different from zero. The effect of teaching experience in the current class is always insignificantly different from zero. There is no evidence of a quadratic class size effect. If class size squared is added to the specification estimated in column 3 of Table VII, the estimate (standard error) for class size is -2.21 (2.86) and for class size squared 0.04 (0.09). The class size estimate in column 3 is basically unaffected if a median regression is run or if the pupils with the very lowest class sizes (less then 9 pupils in a class) are excluded.

In the difference-in-differences specification, the class size estimate is the difference between the class size estimate in a school period regression, and the class size estimate in a summer regression. To see what the separate contributions to the class size estimate are, we estimate seasonal regressions in Table VIII. In columns 2 and 4 we see that, surprisingly, class size in the sixth grade is positively related to summer learning between the fifth and the sixth grades. The explanation for this result is likely to be that in specifications (3) and (6), the fixed learning effect is not eliminated. Because this effect is probably positively correlated with family background, and because we know from Table II that family background and class size are positively correlated, including class size in these specifications, might just proxy for the fixed learning effect. As can be seen in columns 1 and 3 in Table VIII, the result that smaller classes increase achievement still holds if we look only at the school year change in achievement. Comparing the class size estimate in column 3 of Table VIII with the one in column 7 of Table VII, shows that the 
estimates are of the same magnitude. This means that if the class size estimates in the difference-in-differences regressions, that control for lagged test score changes, are believable, a regression of test score changes over the school year on class size would give a class size estimate close to the truth. However, the seasonal regressions in columns 3 and 4, where initial achievement level is controlled for, show very similar results as in columns 1 and 2. It is therefore surprising that the class size estimates in Table VII, using the difference-in-differences model, differ substantially depending on whether or not initial achievement is assumed to have an effect on achievement change.

Why then do estimations of equations' (5) and (9) give so different class size estimates? If we look at row 5 of Table VII, where the estimates on the lagged changes in test scores are shown, we note unreasonable large negative estimates on lagged achievement changes. ${ }^{34}$ If lagged test score is unrelated to the growth in test scores, the estimate of $\gamma-1$ should be zero. Surprisingly, this estimate indicates that previous test score is strongly negatively related to achievement growth. In Table VII we get estimates close to minus one (that is $\gamma=0$ in equation (9)) on lagged achievement. Since these estimations require the restriction $\gamma_{1}=\gamma_{2}=\gamma$ to hold, it would mean that in equations (6) and (7), achievement is unrelated to previous achievement, holding the fixed learning effect constant. This could only be true if the fixed achievement effect, $A_{i 0}$, has no influence on achievement level in sixth grade. This means that pupils with the same learning rate, the same previous family background and who have gone to schools of similar quality, would have the same achievement level in sixth grade. One possible reason for this estimate on lagged achievement in Table VII, is that lagged achievement has different effects on achievement level at the end of the school period and at the end of 
the summer. This is also implied by the estimates in row 5 in columns 3 and 4 of Table VIII. The estimate on achievement level at the beginning of the period is negative $(-0.114)$ and significant in the summer regression, but close to zero (-0.006) and insignificant in the school period regression. If the summer regression is estimated, without controls for the teacher and class size variables, the estimate (standard error) on lagged achievement level is $-0.102(0.035)$, adjusting for measurement error in test scores. The difference between the initial achievement levels in the school and summer period regressions is statistically significant, whether or not class size and the teacher variables are included in the summer regression. $^{35}$ However, since the fixed learning effect is not eliminated in these estimations, we do not know if the lagged achievement estimates are consistent.

If the inconsistency in the estimates on initial achievement levels is the same in the summer and school period regressions, the difference between these estimates will however be consistently estimated. Since this difference is estimated to be positive, this implies that the class size estimates in columns 5-8 in Table VII are inconsistent, since the class size parameter is not identified using the dynamic fixed effect model in equation 9. (see the discussion in section II). It is however easy to show that estimation of equation (8), using the pre-summer test score as instrument for the summer test score change, gives the following asymptotic expression for the $\gamma_{2}$-estimate: $p \lim \hat{\gamma}_{2}=\gamma_{2}-\Delta \gamma /(1-\pi)$, where $\pi$ is the estimated regression coefficient from a regression of test scores in fall of the sixth grade on test scores in spring of the fifth grade. This estimate is 0.67 (not correcting for measurement error in test score levels), conditional on the same variables as in Table 8 . Assuming that we know $\Delta \gamma$ to be 0.10 (which is the difference between the estimates from 
Table 8), we get that $p \lim \hat{\gamma}_{2}=\gamma_{2}-0.3$. Hence the bias can is this setting be sizable. Note that this would also bias the class-size estimate and that correcting for this would make the class size estimate more negative. To illustrate this we estimate equation (8) with pre-summer test scores as an instrument for the summer test score change in the first stage, also controlling for class size and the usual variables. We then estimate the schoolyear test score change as function of the predicted first stage summer test score change, class size and the usual variables and the pre-summer test score with a coefficient restricted to 0.10 , in the second stage. The estimate on class size is then -0.64 . Hence, the restriction imposed on equation (9) might partly explain the difference between the class size estimates in columns 1-4 and columns 5-8 in Table VII. Note that also adjusting for measurement errors in test score levels further converge the estimates towards the magnitudes reported in column 1-4 of Table $7 .{ }^{36}$ Based on this we conclude that the class size estimates using the dynamic fixed effect model, just below -0.4 in Table VII, are likely to understate the positive effect of smaller classes of achievements.

It is probably likely however, that the fixed learning effect is positively correlated with the lagged test score levels in equations (6) and (7). If this is the case, the class size estimates in columns 1-3 of Table VII, just below -1 , are too negative. Hence we conclude that the true class size estimate probably lies somewhere between -0.4 and -1 .

\section{Difference-in-differences Regressions with Heterogeneous Class Size Effects}

To assess whether the effect of class size on achievement is systematically related to pupils' social backgrounds, interaction terms are added to the difference-in-differences model. Table IX shows that for math class sizes, strong evidence suggests that pupils, 
with non-Swedish parents, benefit more from smaller classes compared with pupils with at least one Swedish parent. The evidence for parents' education and family income are mixed however. Since these variables are highly correlated, I also interacted class size with a measure of social background. This measure was derived by simply standardize education and family income and taking the average value of these two standardized variables. Hence, this social background measure weights education and family income equally. The results are that in column 2 , without controlling for lagged test scores, the interaction term is positive but insignificant. Controlling for lagged test scores, however, the interaction term is positive and significant. Hence, there is only some evidence that pupils with parents that have low education and income gain more from smaller classes. If a median regression is estimated, using the same specification as in column 2 , the estimate on the interaction between class size and the social background measure is very close to zero. The estimate on the interaction between class size and non-Swedish parents gets more negative but with a larger standard error ( $p$-value is 0.08). Excluding the pupils with the very lowest class sizes does not change the results.

The correlation's in Table II showed that being non-Swedish clearly is associated with having lower family incomes and education. But being non-Swedish is probably in itself a proxy for low socioeconomic status. ${ }^{37}$ So I proceed by comparing a pupil whose parents are Swedish and have education and family income in the 90th percentile, with a pupil whose parents are non-Swedish, and have education and family income in the 10th percentile. $^{38}$ The first pupil is said to have parents with high socioeconomic status and the second pupil is said to have parents with low socioeconomic status. In columns 2 and 4 of Table IX, the low socioeconomic-status pupil gets class size estimates of -2.66 and -2.00 , 
respectively. The high socioeconomic-status pupil gets class size estimates of -0.25 and 0.37, respectively. So pupils with parents that are non-Swedish and have low education and income do gain relatively more from smaller math classes.

If the analysis in this section is done using the measure of regular class size instead of the measure of math class size, the conclusions are similar to the results when the math class size measures are used. In general the positive effect of smaller classes on achievement is somewhat larger using the regular class size measure. An exception is that the class size effect appears to be homogenous, i.e. it is not significantly different with respect to the family background and demographic variables. The results using the regular class size measure are available from the author upon request.

\section{Sensitivity Analysis}

It is possible that the timing of the tests, that is, that the tests were not done immediately after and before the summer break, has an effect on the results. By assuming linearity of learning over the school year, I predicted percentile ranks just before and after the summer breaks, as outlined in section III. To facilitate comparison, I scaled up the

summer change in learning to 38 weeks, which is the length of the school year. ${ }^{39}$ Table X shows that the positive achievement effect of smaller classes is not overturned. Instead, the effect is strengthened.

In column 1 of Table XI, an attempt to instrument for class sizes in sixth grade by class size in fifth grade is done. Because the difference-in-differences specification eliminates the effect from previous class sizes and eliminates the fixed learning effect, this instrumental variable should be unrelated to the dependent variable, conditional upon 
current class size. Also, if there are measurement errors in the class size measure, and these measurement errors are classical and uncorrelated with each other between grades, the class size estimate in column 1 will correct for this inconsistency. The estimate increases to a larger than two percentile rank effect on achievement from lowering class size with one pupil. ${ }^{40}$ In column 2 , math class size in sixth grade is instrumented for by regular class size in the same grade. The class size effect is estimated to be somewhat larger compared to column $1 .^{41}$

An important identifying assumption, that the fixed learning effects are the same during the summer vacation and the school year, is underlying the estimations so far. It could however be the case that children are less keen to make use of their ability to learn outside school during the summer (i.e. children do not trying to learn as intensive during the summer as during the school year). If this "will-to-learn" is independent of the unobserved ability of the pupil, it is just captured in the constant terms, which are allowed to differ between the school year and the summer in equations' (3) and (4). But it is reasonable to assume that children for instance do homework during the school year, but not during the summer, and it could of course be the case that high ability children more easily transfer done homework to achievement gains. We would then expect the fixed learning effect to be more important for learning during the school year compared to the summer vacation. If we relax the assumption of identical fixed learning effects, equations' (3) and (4) can be expressed as:

$$
\begin{aligned}
& \Delta A_{i t, 1}=\kappa_{1}+\alpha_{1} F_{i t}+\phi_{1} \delta_{i}+\varepsilon_{i t, 1} \\
& \Delta A_{i t, 2}=\kappa_{2}+\alpha_{2} F_{i t}+\beta S_{i t}+\phi_{2} \delta_{i}+\varepsilon_{i t, 2},
\end{aligned}
$$


where $\phi_{1}$ and $\phi_{2}$ scales the fixed learning effects differently during the summer vacation and during the school year. Taking the difference between equations' (11) and (10), we get:

$$
\Delta A_{i t, 2}-\Delta A_{i t, 1}=\kappa^{\prime}+\beta S_{i t}+\left(\phi_{2}-\phi_{1}\right) \delta_{i}+\Delta \varepsilon_{i t, 2} .
$$

The difference between equation (12) and equation (5) is that the fixed learning effect is still present in equation (12), if $\phi_{1} \neq \phi_{2}$.

Is then the assumption that $\phi_{1}=\phi_{2}$, a reasonable one to make? In row 7 of Table VII, p-values from tests of whether the effect of family background and demographic variables are eliminated by the difference-in-differences specification are shown. These variables are jointly insignificant in all specifications (p-values $>0.60)$. This is important since this at least indicates that the assumption that the fixed learning effect, $\delta_{i}$, is the same in equations (3) and (4), is reasonable to make.

If these family background and demographic variables are poor proxies for the unobserved fixed learning effect, there could still be the case that children do make use of their learning ability outside schools to a higher degree during the school year then during the summer, in which case $\phi_{2}>\phi_{1}$. Since the fixed learning effect is highly likely to be positively correlated with parents' socioeconomic status and pupils' achievement levels, the negative class size estimate is biased away from being negative, since the socioeconomic and test score level variables are positively correlated with class size (see Table II and Table V). Hence the estimated positive effect of smaller classes on achievement, found earlier, would actually underestimate the true effect. Intuitively this is because we might difference out only a part of the fixed learning effect. 
Another potential problem is due to the test distributed to the pupils. Since identical questions were asked at all three occasions, observed test score changes might partly be due to children learning the questions and how to solve them each time the do the test, so that test score changes do not entirely reflect true achievement changes. Lindahl (2000) investigates this issue about possible re-test bias further and find that a part of the achievement change observed is indeed due to re-test effects. By using the fact that some of the pupils did not take all of the four parts of the test at first (the spring fifth grade) test occasion, re-test effects can be tested for by comparing achievement changes over the summer on test parts were pupils did take the test parts in both occasions (this estimate is partly due to re-test bias), with achievement changes over the summer on test parts were the pupils did not take the test before summer but took the test for the first time after the summer (this estimate is not due to re-test bias). The scores on the test part the pupils did not take before summer, is imputed using the scores on the test parts they did take before summer. $^{42}$

It is important to note that if the re-test bias vary between pupils, but is the same for the summer and school year test score change, then the estimates using equations (5) and (9), will be consistent. This is because pupil specific re-test effects will be captured in the pupil fixed learning effect, which is differenced out in the difference-in-difference regressions. Hence, even if the higher ability pupils remember the questions better then their low-ability peers, this will lead to consistent estimates. What is the important issue for the results in this paper is to correct the scores that are not due to re-test bias, since some pupils did not take all the four test parts each time. If we do correct the achievement changes for re-test effects, by subtract the score due to re-test effects from the total scores 
(assumption that the same re-test bias is present at the school-year achievement change), the estimates are not significantly different. For instance, in Column 3 of Table VII, the retest bias corrected class size estimate (standard error) is $-0.89(0.28)$. Hence, the conclusions from this sensitivity analysis are that while re-test bias does exist, it does not appear too seriously bias the class size estimates.

\section{Conclusions}

In this paper, I have presented a new way to estimate the effect of class size on scholastic achievement. I used that schools are only in session during the school period and out of session during the summer. By taking the difference between school period and summer test score changes, I was able to isolate the effect of school characteristics on achievement. An advantage with this identification strategy is that it is possible to apply to most countries or regions, as long as the break in schooling/teaching are sufficiently long. The data needed should also be relatively easy to collect. Hence, this identification strategy has important advantages over those relying on some country-specific exogenous variation in class sizes.

I also compared this method to the classical, value-added model used by many previous analyses. This last method has often shown weak effects from class size on scholastic achievement. This is also the case in this paper. When the difference-indifferences model is used, positive effects from smaller classes on achievement were found. The basic difference-in-differences estimations give class size estimates somewhere between -0.4 and -1 . The sensitivity analysis suggested, however, that the positive effect of smaller classes on achievement might even be understated. Hence we 
conclude that -0.4 is likely to be a lower bound estimate of the positive effect of smaller classes. I also find that pupils whose parents are from non-Swedish families benefit more from smaller math classes. A comparison of my results to the results in Krueger [1999] can be done by noting that there a one-pupil decrease in class size was estimated to yield almost a one percentile rank higher achievement, on average. The estimates in this paper are not very far from that result.

The most likely reason for the differences between the class-size estimates when using the value-added specification and the difference-in-differences specification is that the fixed learning effect fails to be eliminated in the value-added specification. In Hanushek, Kain and Rivkin [1998], the difference in achievement growth between subsequent grades is used as a dependent variable. This also eliminates the fixed learning effect. And since they still get small effects of smaller classes on achievement, it could be argued that unobserved individual specific factors do not bias estimates using the valueadded model. However, the drawback in using the difference-in-differences in achievement growth in subsequent grades as dependent variable is that this requires using changes in class sizes between grades as the independent variable. The reliability ratio for the change in class size in subsequent grades is likely to be much lower than the reliability ratio for the class size within a specific grade level. Correcting for this errors-inmeasurement problem could produce a significantly higher estimate (using the difference in achievement growth in subsequent grade specification) than when the traditional valueadded model is used. So bias from not eliminating the fixed learning effect could still produce large biases in class-size estimates based on the traditional value-added specification. 
In a recent survey of class size research, Hanushek [1998] argues that "Most discussions of reducing class size begin with an assertion that student performance will increase if only class sizes can be reduced, a proposition shown to be generally erroneous." Instead, Krueger [1998] argues that "The research suggests to me that an increase in class size, especially in the early grades, would lower the average student's performance." These different conclusions seems to be due to Hanushek [1998] relying mainly on estimates that use the value-added estimation method, whereas Krueger [1998] relies mainly on the results from the Tennessee class size experiment. This paper might have solved a puzzle behind these different views, because the value-added specification has been shown to not capture the effect of class size on achievement accurately because of its failure to eliminate unobservable factors that have an independent effect on learning. 


\section{References}

Anderson, T. W. and Cheng Hsiao, "Estimation of Dynamic Models With Error Components," Journal of the American Statistical Association, LXXVI (1981), 598-606.

Angrist, Joshua D. and Alan B. Krueger, "Empirical Strategies in Labor Economics," in Orley Ashenfelter and David Card, ed's, Handbook of Labor Economics vol. 3 (North Holland, 1999).

Angrist, Joshua D. and Victor Lavy, “ Using Maimonides' Rule to Estimate the Effect of Class Size on Scholastic Achievement," Quarterly Journal of Economics, CXIV (1999), 533-575.

Arellano, Manuel, "A Note on the Anderson-Hsiao Estimator for Panel Data," Economics Letters, XXXI (1989), 337-341.

Boozer, Michael and Cecilia Rouse, 'Intraschool Variation in Class Size: Patterns and Implications," Working paper \#344, Industrial Relations Section, Princeton University, June 1995.

Burtless, Gary, ed., Does Money Matter? The Effect of School Resources on Student Achievement and Adult Success (Washington, DC: Brookings Institution, 1996).

Case, Anne and Angus Deaton, "School Quality and Educational Outcomes in South Africa," Quarterly Journal of Economics, CXIV (1999), 1047-1084.

Card, David, and Alan B. Krueger, "Does School Quality Matter? Returns to Education and the Characteristics of Public Schools in the United States," Journal of Political Economy, C (1992), 1-40.

Cronbach, Lee J., "Coefficient alpha and the internal structure of tests," Psychometrika, XVI (1951), 297-334.

Dobbelsteen, Simone, Jesse Levin and Hessel Oosterbeek, "The Causal Effect of Class Size on Scholastic Achievement: Distinguishing the Pure Class Size Effect from the Effect of Changes in Class Composition," mimeo, December 1998.

Finn, Jeremy D. and Charles M. Achilles, "Answers and Questions About Class Size: A Statewide Experiment," American Educational Research Journal, XXVII (1990), 557-577.

Hanushek, Eric A., "Conceptual and Empirical Issues in the Estimation of Educational Production Functions," Journal of Human Resources, XIV (1979), 19-41.

, "The Economics of Schooling: Production and Efficiency in Public Schools," Journal of Economic Literature, XXIV (1986), 1141-1177.

, "The Trade-off between Child Quantity and Quality," Journal of Political Economy, C (1992), 84-117.

"The Evidence on Class Size," Occasional Paper Number 98-1, W. Allen Wallis Institute of Political Economy, University of Rochester, February 1998.

Hanushek, Eric A., and Lori L Taylor, "Alternative Assessments and the Performance of Schools: Measurement of State Variations in Achievement," Journal of Human resources, XXV (1990), 179-201.

Hanushek, Eric A., John F. Kain and Steven G. Rivkin, "Teachers, Schools and Academic Achievement," Working Paper, The Cecil and Ida Green Center for the Study of Science and Society, April 2000. 
Hedges, Larry V., Richard Laine, and Rob Greenwald, "Does Money Matter? A MetaAnalysis of Studies of the Effects of Differential School Inputs on Student Outcomes," Educational Researcher, XXIII (1994), 5-14.

Hoxby, Caroline M., "The Effects of Class Size and Composition on Student Achievement: New Evidence from Natural Population Variation," Quarterly Journal of Economics, CXV (2000), 1239-1285.

Krueger, Alan B., "Reassessing the View that American Schools are Broken," Federal Reserve Bank of New York Economic Policy Review, IV (1998), 29-43. , "Experimental Estimates of Education Production Functions," Quarterly Journal of Economics, CXIV (1999), 497-532.

Krueger, Alan B., and Diane M. Whitmore, "The Effect of Attending a Small Class in the Early Grades on College-Test Taking and Middle School Test Results: Evidence from Project STAR.” Forthcoming Economic Journal, 2000.

Lazear, Edward P., "Educational Production," NBER Working Paper No. W7349, September 1999.

Lindahl, Mikael. "Summer Learning and the Effects of Schooling: Evidence from Sweden," in Studies of Causal Effects in Empirical Labor Economics, $\mathrm{PhD}$ thesis (SOFI, Stockholm University, Akademitryck 2000).

Moffitt, Robert A., "Symposium on School Quality and Educational Outcomes: Introduction," Review of Economics and Statistics," LXXVIII (1996), 559-561.

National Agency for Education, "Samband mellan resurser och resultat: En studie av landets grundskolor med elever i årskurs 9. Skolverkets rapport nr 170, (1999). 


\section{Endnotes}

1. See, for example, Card and Krueger [1992], the special issue of Review of Economics and Statistics, Moffitt [1996], and Burtless [1996].

2. See Finn and Achilles [1990].

3. Another reason why this literature is highly debatable might be the lack of theoretical modeling to guide and interpret the empirical work in this area. For an exception, see Lazear [1999].

${ }^{4}$ Throughout the paper learning is taken to mean the change in achievement level between two points in time, hence it can take on negative as well as positive values.

5. For a detailed description of the data and the sampling design, see Lindahl [2000].

6. The reason for using the same test at all three occasions were that in Lindahl [2000], the interest were partly on absolute test score changes during the school year and during the summer.

7. Equation (1) can also be written (ignoring the constant), as $A_{i t}=\sum_{j=0}^{t-1} \lambda^{j} \phi F_{i t-j}+\sum_{j=0}^{t-1} \lambda^{j} \beta S_{i t-j}+\frac{1-\lambda^{t}}{1-\lambda} v_{i}+\sum_{j=0}^{t-1} \lambda^{j} u_{i t-j}$, where achievement level for pupil $i$ is a function of all current and previous family background and school characteristics.

8. It is not obvious whether or not lagged test scores should be included as an explanatory variable. One argument in favor of doing this is that it is probably easier for weak pupils to improve on tests due to their low starting knowledge. Another argument is that we cannot know a priori that the design of the test is such that an absolute improvement in test scores is translated into a comparable absolute advantage in mathematical knowledge in all parts of the test score distribution. An argument against including lagged test scores as an explanatory variable is that in a dynamic specification, if test scores are measured with error, the estimates of all parameters will be biased. In this paper, I present estimates with and without lagged test scores.

9. For a more extensive discussion of the value-added model, see Hanushek [1979] and Hanushek and Taylor [1990]. 
10. Note that we have assumed that $F_{i t}$ is the same at the end of the summer and at the end of the school year.

11. By inserting equation (6) into equation (7), we get $A_{i t, 2}=\theta+\phi F_{i t}+\beta S_{i t}+\lambda A_{i T-1,2}+v_{i}+u_{i t}, \quad$ where $\theta=\kappa_{2}+\gamma_{2} \kappa_{1}, \quad \phi=\alpha_{2}+\alpha_{1} \gamma_{2}, \quad \lambda=\gamma_{1} \gamma_{2}$, $v_{i}=\left(1+\gamma_{2}\right) \delta_{i}$ and $u_{i t}=\gamma_{2} \varepsilon_{i t, 1}+\varepsilon_{i t, 2}$. This is the equivalence of equation (2) in the previous

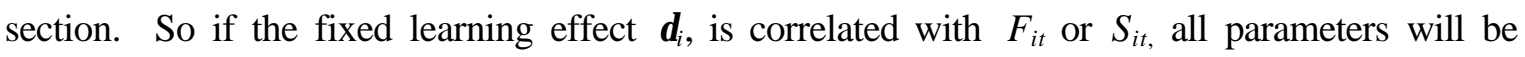
estimated inconsistently. The difference between this equation and equation (2) is that $\gamma, \alpha$ and $\varepsilon_{i t}$ here are allowed to have different values at the end of the summer and school period t.

12. Lindahl [2000], using the same data as in this paper, find no statistically significant difference for the effect of social background, on summer- and school year learning. However, pupils with non-Swedish parents learn relatively more during the school year, unconditional on schooling characteristics. This is however not the case conditional on schooling characteristics. Observe that the restriction $\alpha_{1}=\alpha_{2}$ is conditional on schooling characteristics. Also, disregarding observable family background variables here do not change anything regarding the identification strategy, outlined in this section. These variables can just be added in the estimations. What is important is that the unobservable family background variables have the same effect over summer and over the school period, conditional on schooling characteristics.

13. This is the recommended method for estimating dynamic panel-data models, based on the analysis by Anderson and Hsiao [1981] and Arellano [1989].

14. Formally, classical measurement error in test scores generate the following estimates from (9), assuming only one S-variable: $p \lim \hat{\beta}_{I V}^{\wedge}=\beta-\gamma(1-R) \frac{k}{d}$ and $p \lim \gamma=\gamma\left[\frac{1-R+d}{d}\right]$, where $R$ is the estimated reliability ratio, $k$ is the estimate from a regression of $\Delta A_{i t, l}$ on $S_{i t}$, and $d$ is the estimate from a regression of $\Delta A_{i t, 1}$ on $A_{i t-1,2}$ minus the product of an estimate of $S_{i t}$ on $A_{i t-1,2}$ 
and the estimate from $\Delta A_{i t, l}$ on $S_{i t}$. Solving for $\beta$ and $\gamma$ generate the measurement error corrected estimates. The principle is the same for more variables included in the regressions. The correction for measurement error in the test scores only slightly changes the unadjusted estimates of $\beta$ in equation (9).

15. Note that with the differences-in-differences model, one is normally referring to models that compare the change in mean over time for one group, with is affected by the causing variable, with the change in mean of another group, that is unaffected by the same variable. In this paper, these groups consist of the same individuals, which is not the case in the usual differencesin-differences model. For a description of the more common differences-in-differences model, see Angrist and Krueger [1999].

16. A question of the teachers' total number of years of schooling was also included in the questionnaire. But because many teachers appear to have interpreted this question as years in school after primary or secondary education, I do not use the answers to this question in the estimations.

17. According to the sixth grade class lists, 701 pupils were available for tests in the fall semester in sixth grade, in those classes that participated in this study (see Lindahl [2000]).

18. The results are not altered if raw scores (or raw scores divided by the standard deviations) instead are used.

19. Note that the test scores in Table 1 are expressed in percentile ranks, but that the mean and standard deviations deviate from the values that is produced from a uniform variable with min and max values of 1 and 100 respectively. The reason is that the test scores are averages of test parts measured in percentile ranks. Also note that if the test scores are expressed as raw scores, the test scores increases over time. The increase in raw scores during the school year is about four times as large as the increase during the summer vacation. If adjustments to re-test bias is made or 
if raw scores are predicted, assuming linear learning, the summer test score change becomes negative, see Lindahl [2000].

20. On average the summer test period is 26.88 weeks, and the school test period is 27.09 weeks.

21. In Lindahl [2000] there is some evidence that raw scores increases during the school year, but at a decreasing rate. However, if the test scores are measured in percentile ranks, as is used in this paper, the evidence of non-linearities weakens. In a regression of the weekly percentile change in test scores on the length between test dates during the school year, controlling for pupil, family, class and teacher characteristics, the estimate is still negative but is now insignificant ( $\mathrm{p}$-vale is 0.124$)$

22. This is done by regressing the learning rate in sixth grade on the class size in sixth grade. I then use the estimated parameters and the residual from this regression, and the class size in fifth grade (which is the only variable where I can observe different values in the two grades), to predict the learning rate in fifth grade. See Lindahl [2000] for details.

23. Results in Lindahl [2000] shows that the absolute achievement increase over the school period is almost four times higher compared to the summer period, when observed test scores are used. This suggests that even though the testing dates in the sample used here are far from ideal, it is still possible to use the test scores to capture learning when pupils are in school and when they are not.

24. The teacher experience variables do in some cases not represent the actual teacher in the math class. In these cases, the experience for the teacher responsible for the regular class, is used.

25. Ideally, this matching should have been done with database information from 19981999. The latest data available for education and family income were from December 1996, which are used in this study. 
26. For eight pupils with missing address information, the averages of that class's education and family income were assigned. This was also done in the additional five cases with missing family-income data.

27. See Boozer and Rouse [1995] for a discussion about bias in class size estimates, using aggregated data.

28. See National Agency for Education (1999).

29. We can create a socioeconomic index by taking the average of the standardized values of parents' years of schooling and logarithm of family income. If we then divide this socioeconomic index into three groups, we get that the mean (standard deviation) of class size is 16.95 (4.36) for the lowest group, 20.49 (3.84) for the middle group and 22.27 (3.14) for the highest group. The mean (standard deviation) in class size for pupils with non-Swedish parents is 16.09 (4.03) and for pupils with Swedish parents it is 21.02 (3.85).

30. A test score reliability that is less than one is thought to be due to, for example, pupils having an unusually bad test day or that the test do not accurately capture math skills.

31. See Cronbach [1951].

32. If test scores in the spring of the fifth grade and the fall of the sixth grade is regressed on class size in fifth grade, conditional on pupils' demographics and family background, the class size estimate is close to zero. The direction of the change in the class size estimate, when these demographic and family background variables are added, is however the same.

33. Note that non-Swedish parents, family income and education are highly correlated, making the standard errors of the estimates of the effect of these variables large. As can be seen by the p-value in row 10 , however, these variables are highly jointly significant.

34. Note that the estimate on lagged achievement change from equation (9) is presented in Table VII as $\gamma-1$, to facilitate comparison with equation (5). 
35. Assuming that the covariance between the estimates is zero, the difference between the estimates is 0.108 and the standard error is 0.046 , with controls for class size and teacher variables. The difference between the estimates is 0.096 , with a standard error of 0.047 , without controls for class size and teacher variables in the summer regression.

36. The formula now becomes: $p \lim \hat{\gamma}_{2}=\gamma_{2} \frac{R-\pi}{1-\pi}-\Delta \gamma \frac{R}{1-\pi}$, where $\mathrm{R}$ is the reliability ratio for pre-summer achievement level. Assuming $\mathrm{R}=0.79$, and assuming the same values as before, we get that $p \lim \hat{\gamma}_{2}=0.36 \cdot \gamma_{2}-0.24$.

37. This is because we are cannot observe all relevant socioeconomic variables. For example, the unemployment rate is significantly higher among immigrants in Sweden.

38. The $10^{\text {th }}$ percentile pupil has parents with 9.80 years of schooling and logarithm of family income that is 11.96 . The $90^{\text {th }}$ percentile pupil has parents with 14.79 years of schooling and logarithm of family income that is 13.30 . Gender is set to 0.5 .

39. The summer vacation in schools in Sweden is 10 weeks and the school year is 42 weeks. However, since the pupils are not present in schools during four weeks of the school year, due to major holidays, the school year is here set to be 38 weeks.

40. In the first stage regression, class size in fifth grade have a highly significant effect on class size in sixth grade (p-value is 0.002).

41. In the first stage regression, regular class size in sixth grade have a weakly significant effect on class size in sixth grade (p-value is 0.059 ).

42. For a sub-sample of the pupils it is even possible to test for re-test bias using within pupil achievement changes between spring of the fifth grade and fall of the sixth grade. When this is done the magnitude of the re-test bias does not change. 
TABLE I: Descriptive Statistics

\begin{tabular}{|c|c|c|c|c|}
\hline & Mean & St. Dev & Min & Max \\
\hline \multicolumn{5}{|l|}{ Test scores (percentile ranks) } \\
\hline Fifth-grade, spring: $A_{i t-1,2}$ & 47.65 & 23.07 & 1 & 99.5 \\
\hline Sixth-grade, fall: $A_{i t, 1}$ & 47.93 & 22.98 & 1 & 96.5 \\
\hline Sixth-grade, spring: $A_{i t, 2}$ & 46.80 & 22.70 & 1.5 & 92 \\
\hline $\begin{array}{l}\text { Change from fifth-grade spring to sixth-grade, } \\
\text { spring: } A_{i t, 2}-A_{i t-1,2}\end{array}$ & -0.85 & 17.24 & -48.5 & 68.5 \\
\hline $\begin{array}{l}\text { Change from fifth-grade, spring to sixth-grade, } \\
\text { fall: } \Delta A_{i t, 1}\end{array}$ & 0.28 & 17.17 & -49.67 & 55.25 \\
\hline $\begin{array}{l}\text { Change from sixth-grade, fall to sixth-grade, } \\
\text { spring: } \Delta A_{i t, 2}\end{array}$ & -1.13 & 15.63 & -48.75 & 49.5 \\
\hline $\begin{array}{l}\text { Change from sixth-grade, fall to sixth-grade, } \\
\text { spring minus change from fifth-grade, spring to } \\
\text { sixth-grade, fall: } \Delta A_{i t, 2}-\Delta A_{i t, 1}\end{array}$ & -1.41 & 27.94 & -98.5 & 85 \\
\hline \multicolumn{5}{|l|}{ Class Sizes } \\
\hline Class Size, fifth grade (Math) & 22.91 & 5.72 & 3 & 32 \\
\hline Class Size, sixth grade (Math) & 19.90 & 4.40 & 5.5 & 25 \\
\hline Class Size, fifth grade (Regular) & 24.86 & 3.83 & 14 & 32 \\
\hline Class Size, sixth grade (Regular) & 23.11 & 4.16 & 13 & 28.5 \\
\hline \multicolumn{5}{|l|}{ Teacher variables, sixth grade } \\
\hline Teacher experience in years & 16.17 & 10.82 & 0.2 & 33 \\
\hline Teacher exp. (years in the class) & 1.62 & 1.04 & 0 & 5 \\
\hline \multicolumn{5}{|l|}{ Pupil and social background variables } \\
\hline Gender (Girl=1) & 0.50 & 0.50 & 0 & 1 \\
\hline Non-Swedish parents=1 & 0.23 & 0.42 & 0 & 1 \\
\hline Parents' education & 12.36 & 1.96 & 7.53 & 19.67 \\
\hline Log(Family Income $)$ & 12.60 & 0.54 & 11.19 & 14.75 \\
\hline
\end{tabular}




\section{TABLE II}

Correlation Matrix for Pupil, Social Background and Class size Variables

\begin{tabular}{|c|c|c|c|c|c|c|c|c|}
\hline & Girl & $\begin{array}{l}\text { Non-Swedish } \\
\text { parents }\end{array}$ & $\begin{array}{l}\text { Parents' } \\
\text { education }\end{array}$ & $\begin{array}{l}\text { Log (family } \\
\text { income) }\end{array}$ & $\begin{array}{l}\text { Class size, fifth } \\
\text { grade (Math) }\end{array}$ & $\begin{array}{l}\text { Class size, sixth } \\
\text { grade (Math) }\end{array}$ & $\begin{array}{l}\text { Class size, fifth } \\
\text { grade (Regular) }\end{array}$ & $\begin{array}{l}\text { Class size, } \mathrm{s} \\
\text { grade (Reg! }\end{array}$ \\
\hline Girl & 1.00 & & & & & & & \\
\hline $\begin{array}{l}\text { Parents' nationality (Non- } \\
\text { Swedish parents=1) }\end{array}$ & $\begin{array}{l}-0.02 \\
(0.55)\end{array}$ & 1.00 & & & & & & \\
\hline Parents' education & $\begin{array}{l}0.03 \\
(0.55)\end{array}$ & $\begin{array}{l}-0.50 \\
(0.00)\end{array}$ & 1.00 & & & & & \\
\hline Log (family Income) & $\begin{array}{c}0.01 \\
(0.77)\end{array}$ & $\begin{array}{l}-0.55 \\
(0.00)\end{array}$ & $\begin{array}{l}0.72 \\
(0.00)\end{array}$ & 1.00 & & & & \\
\hline $\begin{array}{l}\text { Class size, fifth grade } \\
\text { (Math) }\end{array}$ & $\begin{array}{l}0.02 \\
(0.69)\end{array}$ & $\begin{array}{l}-0.40 \\
(0.00)\end{array}$ & $\begin{array}{l}0.37 \\
(0.00)\end{array}$ & $\begin{array}{l}0.34 \\
(0.00)\end{array}$ & 1.00 & & & \\
\hline $\begin{array}{l}\text { Class size, sixth grade } \\
\text { (Math) }\end{array}$ & $\begin{array}{l}-0.01 \\
(0.86)\end{array}$ & $\begin{array}{l}-0.47 \\
(0.00)\end{array}$ & $\begin{array}{l}0.51 \\
(0.00)\end{array}$ & $\begin{array}{l}0.47 \\
(0.00)\end{array}$ & $\begin{array}{l}0.60 \\
(0.00)\end{array}$ & 1.00 & & \\
\hline $\begin{array}{l}\text { Class size, fifth grade } \\
\text { (Regular) }\end{array}$ & $\begin{array}{l}-0.04 \\
(0.31)\end{array}$ & $\begin{array}{l}-0.29 \\
(0.00)\end{array}$ & $\begin{array}{l}0.21 \\
(0.00)\end{array}$ & $\begin{array}{l}0.20 \\
(0.00)\end{array}$ & $\begin{array}{l}0.61 \\
(0.00)\end{array}$ & $\begin{array}{l}0.20 \\
(0.00)\end{array}$ & 1.00 & \\
\hline $\begin{array}{l}\text { Class size, sixth grade } \\
\text { (Regular) }\end{array}$ & $\begin{array}{l}-0.09 \\
(0.04)\end{array}$ & $\begin{array}{l}-0.24 \\
(0.00)\end{array}$ & $\begin{array}{l}0.19 \\
(0.00)\end{array}$ & $\begin{array}{l}0.13 \\
(0.00)\end{array}$ & $\begin{array}{l}-0.06 \\
(0.17)\end{array}$ & $\begin{array}{l}0.42 \\
(0.00)\end{array}$ & $\begin{array}{l}0.31 \\
(0.00)\end{array}$ & 1.00 \\
\hline
\end{tabular}

Notes: Number of observations is 556. P-values for test of no correlation are in parentheses. 
TABLE III

Correlation Matrix of Test Scores

\begin{tabular}{l|lll} 
& Fifth-grade, spring & Sixth grade, fall & Sixth grade, spring \\
\hline Fifth grade, spring & 1.00 & & \\
Sixth grade, fall & 0.72 & 1.00 & \\
Sixth grade, spring & 0.72 & 0.77 & 1.000
\end{tabular}

Notes: Number of observations is 556. Test scores are measured in percentile ranks. 
TABLE IV

Correlation Matrix of Scores of the Test Parts in Fifth Grade

\begin{tabular}{l|llll} 
& Part B & Part C & Part D & Part E \\
\hline Part B & 1.00 & & & \\
& $(527)$ & & & \\
Part C & 0.56 & 1.00 & & \\
& $(512)$ & $(529)$ & & \\
Part D & 0.49 & 0.49 & 1.00 & \\
& $(453)$ & $(457)$ & $(478)$ & 1.00 \\
Part E & 0.50 & 0.44 & 0.43 & $(469)$ \\
& $(445)$ & $(451)$ & $(434)$ &
\end{tabular}

Notes: Number of observations used for each correlation is in parenthesis. Test scores are measured in percentile ranks. 
TABLE V

Level Regressions

\begin{tabular}{|c|c|c|c|c|c|}
\hline & \multicolumn{5}{|c|}{ Dependent variable: Test score in spring of the sixth grade. } \\
\hline & $\begin{array}{l}\text { OLS } \\
(1)\end{array}$ & $\begin{array}{l}\text { OLS } \\
(2)\end{array}$ & $\begin{array}{l}\text { OLS } \\
(3)\end{array}$ & $\begin{array}{l}\text { School-FE } \\
\text { (4) }\end{array}$ & $\begin{array}{l}\text { School-FE } \\
\text { (5) }\end{array}$ \\
\hline $\begin{array}{l}\text { Class Size, sixth grade } \\
\text { (Math) }\end{array}$ & $\begin{array}{l}1.51 \\
(0.31)\end{array}$ & $\begin{array}{c}0.81 \\
(0.33)\end{array}$ & $\begin{array}{l}0.84 \\
(0.35)\end{array}$ & $\begin{array}{l}1.13 \\
(0.73)\end{array}$ & $\begin{array}{l}0.87 \\
(0.68)\end{array}$ \\
\hline Teacher experience & & & $\begin{array}{l}0.32 \\
(0.25)\end{array}$ & & \\
\hline $\begin{array}{l}\text { Teacher experience } \\
\text { Squared }\end{array}$ & & & $\begin{array}{l}-0.01 \\
(0.01)\end{array}$ & & \\
\hline $\begin{array}{l}\text { Teacher experience in } \\
\text { class }\end{array}$ & & & $\begin{array}{l}-0.92 \\
(0.96)\end{array}$ & & \\
\hline Girl & & $\begin{array}{l}0.80 \\
(2.40)\end{array}$ & $\begin{array}{l}0.81 \\
(2.37)\end{array}$ & & $\begin{array}{l}0.88 \\
(2.27)\end{array}$ \\
\hline Non-Swedish parents & & $\begin{array}{l}-4.44 \\
(3.41)\end{array}$ & $\begin{array}{l}-4.83 \\
(3.18)\end{array}$ & & $\begin{array}{l}-7.78 \\
(4.18)\end{array}$ \\
\hline Parents' education & & $\begin{array}{c}1.33 \\
(0.99)\end{array}$ & $\begin{array}{l}1.33 \\
(0.92)\end{array}$ & & $\begin{array}{l}1.18 \\
(0.74)\end{array}$ \\
\hline Log (family Income) & & $\begin{array}{c}3.36 \\
(4.32)\end{array}$ & $\begin{array}{l}3.42 \\
(4.11)\end{array}$ & & $\begin{array}{l}5.08 \\
(4.00)\end{array}$ \\
\hline $\begin{array}{l}\text { School } \\
\text { Dummies }\end{array}$ & No & No & No & Yes & Yes \\
\hline $\begin{array}{l}\text { p-value: test of no joint } \\
\text { effect of pupil and social } \\
\text { background variables }\end{array}$ & - & 0.01 & 0.01 & 0.00 & 0.00 \\
\hline $\mathrm{R}^{2}$ & 0.085 & 0.124 & 0.127 & 0.124 & 0.178 \\
\hline
\end{tabular}




\section{TABLE VI}

Value-Added Regressions

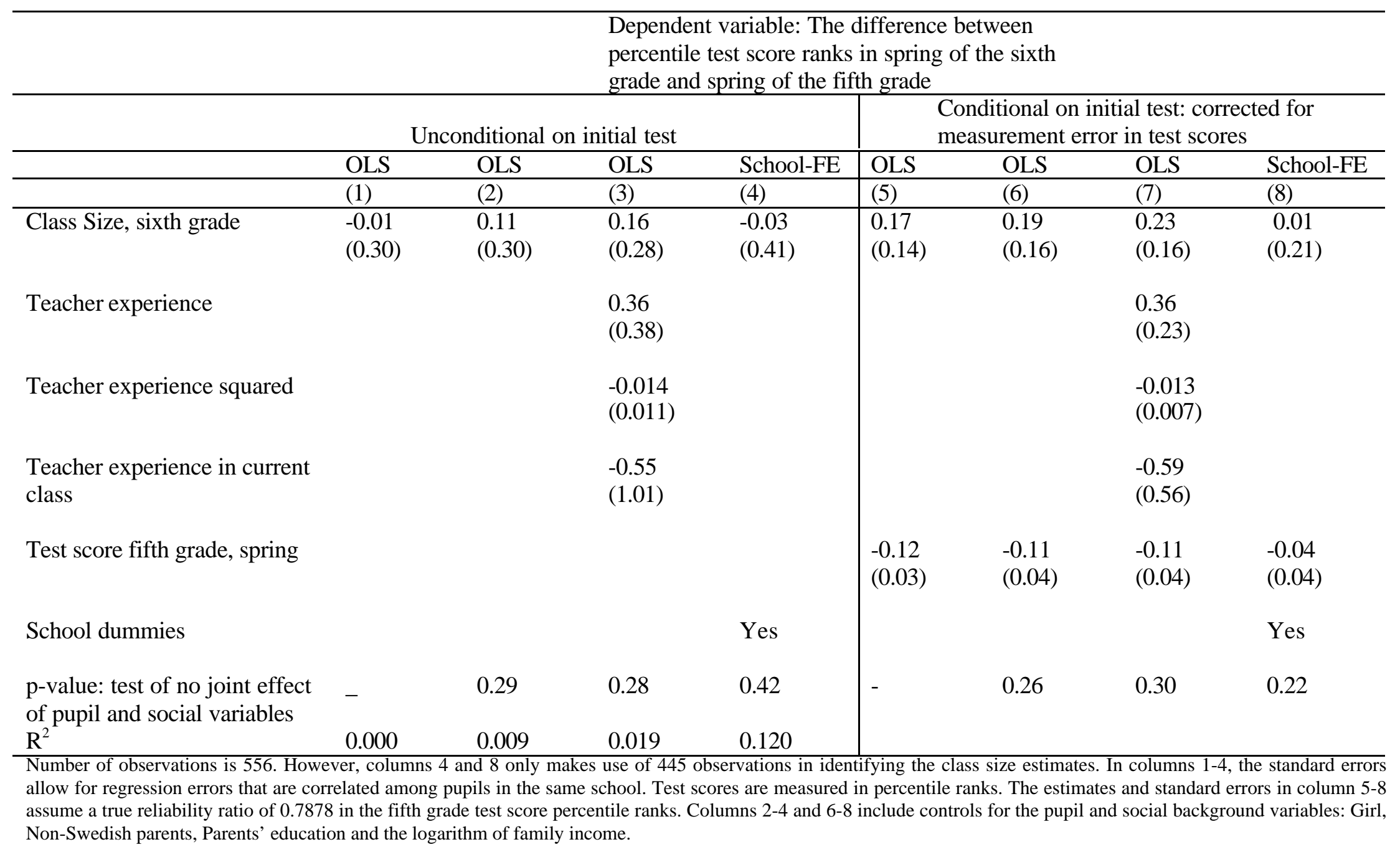


TABLE VII: Difference-in-differences Regressions

\begin{tabular}{|c|c|c|c|c|c|c|c|c|}
\hline & & \multicolumn{7}{|c|}{$\begin{array}{l}\text { Dependent variable: The difference between the school period and the summer } \\
\text { period changes in percentile test score ranks }\end{array}$} \\
\hline & & \multicolumn{3}{|c|}{$\begin{array}{l}\text { Unconditional on initial } \\
\text { test }\end{array}$} & \multicolumn{4}{|c|}{$\begin{array}{l}\text { Conditional on initial test: } \\
\text { Corrected for endogeniety and } \\
\text { measurement error in test scores }\end{array}$} \\
\hline & OLS & OLS & OLS & School-FE & IV & IV & IV & IV, School-FE \\
\hline & (1) & (2) & (3) & (4) & (5) & (6) & (7) & (8) \\
\hline Class Size, sixth grade & $\begin{array}{l}-0.77 \\
(0.23)\end{array}$ & $\begin{array}{l}-0.95 \\
(0.32)\end{array}$ & $\begin{array}{l}-0.98 \\
(0.26)\end{array}$ & $\begin{array}{l}-1.38 \\
(0.66)\end{array}$ & $\begin{array}{l}-0.36 \\
(0.14)\end{array}$ & $\begin{array}{l}-0.38 \\
(0.21)\end{array}$ & $\begin{array}{l}-0.37 \\
(0.18)\end{array}$ & $\begin{array}{l}-0.77 \\
(0.34)\end{array}$ \\
\hline Teacher experience & & & $\begin{array}{l}0.77 \\
(0.81)\end{array}$ & & & & $\begin{array}{l}0.55 \\
(0.32)\end{array}$ & \\
\hline Teacher experience squared & & & $\begin{array}{l}-0.019 \\
(0.025)\end{array}$ & & & & $\begin{array}{l}-0.016 \\
(0.010)\end{array}$ & \\
\hline $\begin{array}{l}\text { Teacher experience in current } \\
\text { class }\end{array}$ & & & $\begin{array}{l}-1.04 \\
(1.11)\end{array}$ & & & & $\begin{array}{l}-0.77 \\
(0.50)\end{array}$ & \\
\hline $\begin{array}{l}\text { Lagged test score change } \\
(\gamma-1)\end{array}$ & & & & & $\begin{array}{l}-1.08 \\
(0.31)\end{array}$ & $\begin{array}{l}-1.07 \\
(0.35)\end{array}$ & $\begin{array}{l}-1.08 \\
(0.36)\end{array}$ & $\begin{array}{l}-0.90 \\
(1.14)\end{array}$ \\
\hline School dummies & No & No & No & Yes & No & No & No & Yes \\
\hline p-value: test of no joint effect & - & 0.74 & 0.61 & 0.85 & - & 0.71 & 0.66 & 0.61 \\
\hline $\mathrm{R}^{2} \mathrm{P}(\mathrm{c})$ & 0.015 & 0.020 & 0.027 & 0.102 & & & & \\
\hline
\end{tabular}

Number of observations is 556. However, columns 4 and 8 only makes use of 445 observations in identifying the class size estimates. The standard errors, in parentheses, allow for regression errors that are correlated among pupils in the same school. Test scores are measured in percentile ranks. The dependent variable, is the change in percentile test scores between the fall and spring of the sixth grade minus the change in percentile test scores between the spring of the fifth grade and fall of the sixth grade. Columns 2-4 and 68 include controls for the pupil and social background variables: Girl, Non-Swedish parents, Parents' education and the logarithm of family income. The estimates and standard errors in column 5-8 assume a true reliability ratio of 0.7878 for test score levels. Lagged test score change is the change in test score percentile rank between fifth grade, spring and sixth grade, fall. Column 5-8 uses the test score percentile rank in fifth grade, spring as instrument for the lagged test score change. 


\section{TABLE VIII}

\section{Summer and School Period Regressions}

\begin{tabular}{|c|c|c|c|c|}
\hline Dependent variable: & $\begin{array}{l}\text { School } \\
\text { period gain }\end{array}$ & $\begin{array}{l}\text { Summer } \\
\text { period gain }\end{array}$ & $\begin{array}{l}\text { School } \\
\text { period gain }\end{array}$ & $\begin{array}{l}\text { Summer } \\
\text { period gain }\end{array}$ \\
\hline & \multicolumn{2}{|c|}{ No Lag } & \multicolumn{2}{|c|}{$\begin{array}{l}\text { Lagged test scores are } \\
\text { controlled for (estimates } \\
\text { adjusted for measurement } \\
\text { error in test scores) }\end{array}$} \\
\hline & OLS & OLS & OLS & OLS \\
\hline & $(1)$ & $(2)$ & (3) & (4) \\
\hline Class size in grade 6 & $\begin{array}{l}-0.41 \\
(0.18)\end{array}$ & $\begin{array}{c}0.57 \\
(0.20)\end{array}$ & $\begin{array}{l}-0.40 \\
(0.14)\end{array}$ & $\begin{array}{c}0.65 \\
(0.16)\end{array}$ \\
\hline Teacher experience & $\begin{array}{c}0.57 \\
(0.32)\end{array}$ & $\begin{array}{l}-0.21 \\
(0.55)\end{array}$ & $\begin{array}{c}0.56 \\
(0.19)\end{array}$ & $\begin{array}{l}-0.21 \\
(0.22)\end{array}$ \\
\hline Teacher experience squared & $\begin{array}{l}-0.016 \\
(0.010)\end{array}$ & $\begin{array}{c}0.002 \\
(0.017)\end{array}$ & $\begin{array}{l}-0.016 \\
(0.006)\end{array}$ & $\begin{array}{c}0.003 \\
(0.007)\end{array}$ \\
\hline $\begin{array}{l}\text { Teacher experience in current } \\
\text { class }\end{array}$ & $\begin{array}{l}-0.79 \\
(0.49)\end{array}$ & $\begin{array}{c}0.24 \\
(0.94)\end{array}$ & $\begin{array}{l}-0.79 \\
(0.48)\end{array}$ & $\begin{array}{c}0.20 \\
(0.55)\end{array}$ \\
\hline Test score at start of period & & & $\begin{array}{l}-0.01 \\
(0.03)\end{array}$ & $\begin{array}{l}-0.11 \\
(0.03)\end{array}$ \\
\hline $\begin{array}{l}\text { p-value: test of no joint effect of } \\
\text { pupil and social background } \\
\text { variables }\end{array}$ & 0.65 & 0.33 & 0.38 & 0.29 \\
\hline $\mathrm{R} 2$ & 0.025 & 0.024 & & \\
\hline
\end{tabular}


TABLE IX

Difference-in-differences Regressions with Heterogeneous Class size Effects

\begin{tabular}{|c|c|c|c|c|}
\hline & \multicolumn{4}{|c|}{$\begin{array}{l}\text { Dependent variable: The difference between the school period and the summer } \\
\text { period changes in percentile test score ranks }\end{array}$} \\
\hline & \multicolumn{2}{|c|}{ No Lag } & \multicolumn{2}{|c|}{$\begin{array}{l}\text { Lag, corrected for endogeneity and } \\
\text { measurement error in test scores }\end{array}$} \\
\hline & OLS & OLS & IV & IV \\
\hline & $(1)$ & (2) & (3) & (4) \\
\hline Girl & $\begin{array}{l}1.07 \\
(2.64)\end{array}$ & $\begin{array}{l}14.06 \\
(11.99)\end{array}$ & $\begin{array}{l}1.21 \\
(1.45)\end{array}$ & $\begin{array}{l}9.04 \\
(5.48)\end{array}$ \\
\hline Non-Swedish parents & $\begin{array}{l}1.22 \\
(4.36)\end{array}$ & $\begin{array}{l}35.31 \\
(11.49)\end{array}$ & $\begin{array}{l}0.94 \\
(1.95)\end{array}$ & $\begin{array}{l}9.99 \\
(5.91)\end{array}$ \\
\hline Parents education & $\begin{array}{l}0.31 \\
(1.30)\end{array}$ & $\begin{array}{l}-6.46 \\
(4.86)\end{array}$ & $\begin{array}{l}0.42 \\
(0.52)\end{array}$ & $\begin{array}{l}-3.45 \\
(1.77)\end{array}$ \\
\hline Log (family income) & $\begin{array}{l}4.60 \\
(4.37)\end{array}$ & $\begin{array}{l}22.70 \\
(12.34)\end{array}$ & $\begin{array}{l}0.15 \\
(2.62)\end{array}$ & $\begin{array}{l}-2.05 \\
(6.75)\end{array}$ \\
\hline Class size in grade 6 (CS6) & $\begin{array}{l}-0.98 \\
(0.26)\end{array}$ & $\begin{array}{l}6.61 \\
(6.07)\end{array}$ & $\begin{array}{l}-0.37 \\
(0.18)\end{array}$ & $\begin{array}{l}-3.55 \\
(3.48)\end{array}$ \\
\hline CS6*Girl & & $\begin{array}{l}-0.64 \\
(0.55)\end{array}$ & & $\begin{array}{l}-0.38 \\
(0.27)\end{array}$ \\
\hline CS6*Foreign & & $\begin{array}{l}-1.96 \\
(0.56)\end{array}$ & & $\begin{array}{l}-0.58 \\
(0.31)\end{array}$ \\
\hline CS6*Parents.education & & $\begin{array}{l}0.32 \\
(0.25)\end{array}$ & & $\begin{array}{l}0.19 \\
(0.08)\end{array}$ \\
\hline CS6*Log (family income) & & $\begin{array}{l}-0.84 \\
(0.58)\end{array}$ & & $\begin{array}{l}0.11 \\
(0.27)\end{array}$ \\
\hline $\begin{array}{l}\text { Lagged test score change } \\
(\gamma-1)\end{array}$ & & & $\begin{array}{l}-1.08 \\
(0.36)\end{array}$ & $\begin{array}{l}-1.12 \\
(0.40)\end{array}$ \\
\hline Mean class size effect & & -0.86 & & -0.23 \\
\hline $\begin{array}{l}\text { p-value: test of no joint } \\
\text { effect of pupil and social } \\
\text { background variables }\end{array}$ & 0.631 & 0.045 & 0.664 & 0.113 \\
\hline $\begin{array}{l}\text { p-value: test of no joint } \\
\text { effect of pupil and social } \\
\text { background variables, } \\
\text { interacted with CS6 }\end{array}$ & & 0.013 & & 0.100 \\
\hline $\mathrm{R} 2$ & 0.027 & 0.044 & & \\
\hline
\end{tabular}


TABLE $X$

Difference-in-Differences Regressions using Predicted Percentile Ranks

\begin{tabular}{|c|c|c|c|c|}
\hline & \multicolumn{4}{|c|}{$\begin{array}{l}\text { Dependent variable: The difference between the school } \\
\text { period and the summer period changes in predicted percentile } \\
\text { test score ranks }\end{array}$} \\
\hline & OLS & OLS & OLS & School-FE \\
\hline & (1) & (2) & (3) & (4) \\
\hline Class Size, sixth grade & $\begin{array}{l}-2.34 \\
(0.60)\end{array}$ & $\begin{array}{l}-2.53 \\
(0.84)\end{array}$ & $\begin{array}{l}-2.54 \\
(0.66)\end{array}$ & $\begin{array}{l}-3.43 \\
(1.56)\end{array}$ \\
\hline Teacher experience & & & $\begin{array}{c}2.91 \\
(1.85)\end{array}$ & \\
\hline Teacher experience squared & & & $\begin{array}{l}-0.08 \\
(0.06)\end{array}$ & \\
\hline $\begin{array}{l}\text { Teacher experience in current } \\
\text { class }\end{array}$ & & & $\begin{array}{l}-3.41 \\
(2.37)\end{array}$ & \\
\hline School dummies & No & No & No & Yes \\
\hline $\begin{array}{l}\text { p-value: test of no joint effect of } \\
\text { pupil and social background } \\
\text { variables }\end{array}$ & - & 0.27 & 0.21 & 0.55 \\
\hline R2 & 0.016 & 0.023 & 0.032 & 0.085 \\
\hline $\begin{array}{l}\text { Notes: Number of observations is } 556 . \\
\text { among pupils in the same school. The t } \\
\text { is the change in predicted percentile te } \\
\text { predicted percentile test scores between } \\
\text { controls for the pupil and social backgro } \\
\text { of family income. The summer break is } \\
\text { which is } 38 \text { weeks long. }\end{array}$ & $\begin{array}{l}\text { standar } \\
\text { score } v \\
\text { scores } \\
\text { e sprin } \\
\text { d varial }\end{array}$ & $\begin{array}{l}\text { parenth } \\
\text { edicted } \\
\text { e fall an } \\
\text { h grade } \\
\text { Jon-Swe } \\
\text { led up t }\end{array}$ & $\begin{array}{l}\text { for regre } \\
\text { ercentile } \\
\text { the six } \\
\text { the sixt } \\
\text {, Parent } \\
\text { to be c }\end{array}$ & $\begin{array}{l}\text { s that are correlat } \\
\text { dependent variab } \\
\text { inus the change } \\
\text { olumns } 2-4 \text { inclu } \\
n \text { and the logarith } \\
\text { to the school ye }\end{array}$ \\
\hline
\end{tabular}




\title{
TABLE XI
}

\section{Difference-in-Differences Regressions using other Class size Measures}

\author{
as Instrumental Variables
}

\begin{tabular}{|c|c|c|}
\hline & \multicolumn{2}{|c|}{$\begin{array}{l}\text { Dependent variable: The difference between the school } \\
\text { period and the summer period changes in percentile } \\
\text { test score ranks }\end{array}$} \\
\hline & IV & IV \\
\hline & (1) & (2) \\
\hline Class Size in grade 6 & $\begin{array}{l}-2.15 \\
(0.88)\end{array}$ & $\begin{array}{l}-2.77 \\
(2.32)\end{array}$ \\
\hline Teacher experience & $\begin{array}{c}0.85 \\
(0.82)\end{array}$ & $\begin{array}{c}0.90 \\
(0.80)\end{array}$ \\
\hline Teacher experience Squared & $\begin{array}{l}-0.020 \\
(0.024)\end{array}$ & $\begin{array}{l}-0.020 \\
(0.024)\end{array}$ \\
\hline Teacher experience in current class & $\begin{array}{l}-0.63 \\
(1.17)\end{array}$ & $\begin{array}{l}-0.42 \\
(1.68)\end{array}$ \\
\hline $\begin{array}{l}\text { p-value: test of no joint effect of pupil } \\
\text { and social background variables }\end{array}$ & 0.29 & 0.71 \\
\hline R2 & - & - \\
\hline $\begin{array}{l}\text { Number of observations is } 556 \text {. The standard er } \\
\text { pupils in the same school. Test scores are m } \\
\text { percentile test scores between the fall and sprir } \\
\text { the spring of the fifth grade and fall of the sixth } \\
\text { variables: Girl, Non-Swedish parents, Parents' } \\
\text { size in fifth grade as an instrument for math cla } \\
\text { an instrument for math class size in sixth grade. }\end{array}$ & $\begin{array}{l}\text { s, in paren } \\
\text { ured in p } \\
\text { of the sixt } \\
\text { ide. All co } \\
\text { cation anc } \\
\text { size in six }\end{array}$ & $\begin{array}{l}\text { ion errors that are correlated amon } \\
\text { pendent variable, is the change ir } \\
\text { ge in percentile test scores betweer } \\
\text { for the pupil and social backgrounc } \\
\text { income. Column } 1 \text { uses math clas } \\
\text { regular class size in sixth grade as }\end{array}$ \\
\hline
\end{tabular}


Figure I

Number of

pupils

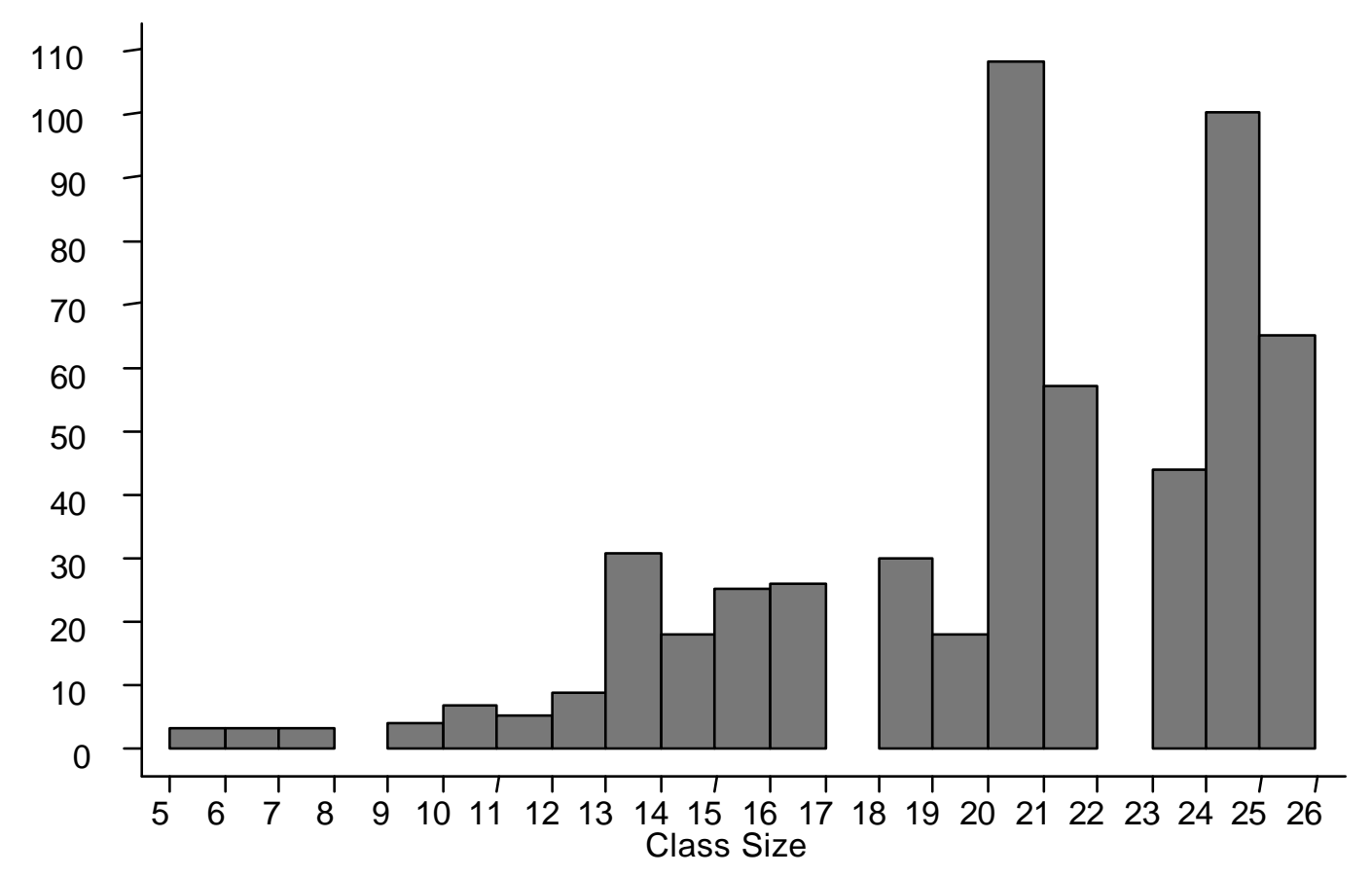

Distribution of Math Class sizes in Sixth Grade 